\title{
Adrenomedullin in rat follicles and corpora lutea: expression, functions and interaction with endothelin-1
}

\author{
Lei Li ${ }^{1}$, Wai-Sum $\mathrm{O}^{2,3^{*}}$ and Fai Tang ${ }^{1,4}$
}

\begin{abstract}
Background: Adrenomedullin (ADM), a novel vasorelaxant peptide, was found in human/rat ovaries. The present study investigated the interaction of ADM and endothelin-1 (ET-1) in follicles and newly formed corpora lutea (CL) and the actions of $\mathrm{ADM}$ on progesterone production in $\mathrm{CL}$ during pregnancy.

Methods: The peptide and gene expression level of adrenomedullin in small antral follicles, large antral follicles and $C L$ was studied by real-time RT-PCR and ElA. The effect of ADM treatment on oestradiol production in 5-day follicular culture and on progesterone production from $\mathrm{CL}$ of different pregnant stages was measured by EIA. The interaction of ADM and ET-1 in follicles and CL at their gene expression level was studied by real-time RT-PCR.

Results: In the rat ovary, the gene expression of Adm increased during development from small antral follicles to large antral follicles and CL. In vitro treatment of preantral follicular culture for 5 days with ADM increased oestradiol production but did not affect follicular growth or ovulation rate. The regulation of progesterone production by ADM in CL in culture was pregnancy-stage dependent, inhibitory at early and late pregnancy but stimulatory at mid-pregnancy, which might contribute to the high progesterone production rate of the $\mathrm{CL}$ at midpregnancy. Moreover, the interaction between ADM and ET-1 at both the production and functional levels indicates that these two vasoactive peptides may form an important local, fine-tuning regulatory system together with $\mathrm{LH}$ and prolactin for progesterone production in rat $\mathrm{CL}$.
\end{abstract}

Conclusions: $\mathrm{As}$ the $\mathrm{CL}$ is the major source of progesterone production even after the formation of placenta in rats, ADM may be an important regulator in progesterone production to meet the requirement of pregnancy.

\section{Background}

First discovered in human pheochromatocytoma tissue in 1993 [1], adrenomedullin (ADM) is highly conserved across species [2-5] and is widely expressed in various organs and tissues, including heart, kidney, lung, adrenal gland [6] and reproductive organs, such as the ovary [7-10], the uterus [7,11], the oviduct [12], the testis [13-16], the prostate [17,18], and the epididymis [19]. ADM belongs to the calcitonin family with a high sequence homology to calcitonin gene-related peptide (CGRP). ADM can bind to the CGRP receptor in several types of tissues [20,21], but specific ADM receptors that are insensitive to CGRP receptor antagonist have been

\footnotetext{
* Correspondence: owaisum@hkucc.hku.hk

2Department of Anatomy, Li Ka Shing Faculty of Medicine, The University of Hong Kong, Pokfulam, Hong Kong SAR, China

Full list of author information is available at the end of the article
}

identified [22]. McLatchie et al. [23] demonstrated that the combination of calcitonin receptor-like receptor (CRLR) and receptor activity-modifying protein (RAMP) isoforms determines the ligand selectivity for CGRP and ADM. Coexpression of CRLR with RAMP1, RAMP2 and RAMP3 produces a CGRP receptor, an ADM1 and ADM2 receptor respectively.

ADM and its mRNA were reported in the follicles and the corpora lutea (CL) of rat [7] and human [9] ovaries and the levels varied during the oestrous cycle [12] or menstrual cycle [10]. In human ovary, $A d m$ mRNA levels were low in the mature follicle but increased in the $\mathrm{CL}$ of the mid-luteal phase and remained high in CL of early pregnancy [9]. Immunoreactive ADM is predominantly localized in granulosa lutein cells at the midluteal phase and at late luteal phase [10]. ADM was also detected in human follicular fluid $[10,24,25]$, with a level

\section{Biomed Central}


higher than that in the plasma [24]. ADM enhances progesterone production in human granulosa cells [10] but suppresses eCG-stimulated progesterone release in newly-formed eCG-primed rat CL [12]. On the other hand, endothelin-1 (ET-1) is known to inhibit progesterone production in the rat CL [26]. The interactions of $\mathrm{ADM}$ and ET-1 have been demonstrated in vascular smooth muscle cells (VSMC) [27-29], the glomerular mesangial cells (MC) in the kidney [30-32], the zona glomerulosa cells (ZGC) of the adrenal gland [33], and Leydig cells [15] and Sertoli cells [16] of the rat testis. In both the Leydig and Sertoli cells, ADM decreases ET-1 level but ET-1 increases ADM level $[15,16]$. The present study investigated the interaction of ADM and ET-1 in follicles and newly-formed CL and the action of $\mathrm{ADM}$ on progesterone production in CL during pregnancy.

\section{Methods}

\section{Superovulation}

Sprague-Dawley rats were obtained from the Laboratory Animal Unit, LKS Faculty of Medicine, the University of Hong Kong. The rats were housed at a constant temperature, humidity, under a 12-hour light-dark cycle (dark period 07:00 to 19:00) and rat chow and water were available ad libitum. All procedures related to animal usage were approved by the Committee on the Use of Live Animals for Teaching and Research, the University of Hong Kong.

Superovulation was induced in 21-23 days old immature female rats by intraperitoneal (i.p.) injection with $30 \mathrm{IU}$ per rat equine chorionic gonadotropin (eCG) and 20IU per rat human chorionic gonadotropin (HCG). An eCG injection was administered at 3:00 p.m. followed by a HCG injection $48 \mathrm{~h}$ thereafter. Small antral follicles (SAF) with a diameter between $250 \mu \mathrm{m}-400 \mu \mathrm{m}$ and large antral follicles (LAF) of a diameter over $900 \mu \mathrm{m}$ were isolated at 24 and $48 \mathrm{~h}$ post-eCG treatment. Newly-formed CL was isolated $24 \mathrm{~h}$ after HCG treatment. All rats were sacrificed by an overdose of sodium pentobarbital $(40 \mathrm{mg} / 100 \mathrm{~g}$ of rat, Alfasan, Woerden, Holland). Follicles and CL were isolated in ice-cold normal saline under a dissecting microscope using two 26G1/2 inch syringe needles. The mRNA levels of $A d m$ and its receptor components - Crlr, Ramp1, Ramp2 and Ramp3 together with Et1 were studied by real-time RTPCR. To study the tissue level of ADM peptide and its secretion, isolated small antral follicles, large antral follicles, and CL from 5 rats were pooled together and divided randomly into a 24-well plate at 9 small antral follicles, 3 large antral follicles or $3 \mathrm{CL}$ per well. Follicles and CL were pre-incubated for $1 \mathrm{~h}$ in $0.5 \mathrm{ml}$ DMEM/F12 medium (Invitrogen life technologies, Carlsbad, CA, USA) and then incubated for another $6 \mathrm{~h}$. The incubation was carried out at $37^{\circ} \mathrm{C}$ under $95 \%$ humidity and $5 \% \mathrm{CO}_{2}$. At the end of the incubation, culture media and, follicles or CL was collected for ADM measurement.

\section{Effect of ADM on follicular development}

Female 21-23 day old SD rats were sacrificed by an overdose of sodium pentobarbital $(40 \mathrm{mg} / 100 \mathrm{~g}$ of rat, Alfasan, Woerden, Holland). Their ovaries were removed and transferred to a pre-warmed follicle isolation medium - Leibovitz's L-15 medium (Invitrogen life technologies, Carlsbad, CA, USA) with $0.1 \%$ BSA, pH 7.6. The ovaries were washed once with L-15 medium, cut into 2-3 pieces each and then transferred to an ovarian-tissue digestion medium $(1 \times \alpha$ MEM with $2 \mathrm{mg} / \mathrm{ml}$ collagenase, $0.2 \mathrm{mg} / \mathrm{ml}$ DNase I; Gibco BRL, Grand Island, NY, USA). Digestion was carried out in a $37^{\circ} \mathrm{C}$ incubator for about $5 \mathrm{~min}$ and then stopped by washing the ovarian tissues with a pre-warmed L-15 medium. The ovarian tissues were further incubated in a fresh L15 medium for $15-30 \mathrm{~min}$ in a $37^{\circ} \mathrm{C}$ incubator. Preantral follicles (diameter of 170-210 $\mu \mathrm{m}$ ) were dissected out, washed for 3 times by $1 \times$ DMEM/F-12 medium and transferred into 96-well plate, one for each well with $100 \mu \mathrm{l}$ follicle culture medium $(1 \times \alpha \mathrm{MEM}$ with $5 \mu \mathrm{g} /$ $\mathrm{ml}$ insulin, $10 \mu \mathrm{g} / \mathrm{ml}$ transferring, $25 \mu \mathrm{g} / \mathrm{ml}$ ascorbic acid, $1 \mathrm{ng} / \mathrm{ml}$ sodium selenite, $5 \mathrm{IU} / \mathrm{ml} \mathrm{FSH}, 0.25 \mathrm{IU} / \mathrm{ml}$ $\mathrm{LH}, 5 \% \mathrm{FBS}$ ) and pre-incubated at $37^{\circ} \mathrm{C}$ for $3 \mathrm{~h}$. Then the culture medium was replaced with a new follicle culture medium with or without $100 \mathrm{nM}$ ADM. The follicular "diameter" (which is the average value of the length and width) was measured under an inverted microscope to make sure they were within $170-210$ $\mu \mathrm{m}$. This was recorded as day 0 measurement. The follicles were cultured in an inverted 96-well plate in a $37^{\circ}$ C, $95 \%$ humidity and $5 \% \mathrm{CO}_{2}$ incubator. Fresh follicle culture medium was changed every other day. The "diameter" of each follicle was measured on days 1, 2 and 4 . The culture medium for incubation from day 2 to day 4 (48 $\mathrm{h}$ incubation) was collected and the oestradiol was assayed by an EIA kit.

\section{ADM and ET-1 interaction in follicles and $\mathrm{CL}$ and regulation of ADM by progesterone and HCG}

The interaction of ADM and ET-1 in large antral follicles and newly-formed CL from superovulation model was studied. Follicles from 5 rats were pooled together and divided randomly into a 24-well plate at 3 follicles per well. They were pre-incubated for $1 \mathrm{~h}$ in $0.5 \mathrm{ml}$ DMEM/F12 medium. The medium was then replaced and receptor antagonists, $1 \mu \mathrm{M} \mathrm{hADM}_{22-52}$ or $1 \mu \mathrm{M}$ hCGRP 8 -37 (Phoenix Pharmaceuticals, Burlingame, CA) was added into the culture medium and incubated for $1 / 2 \mathrm{~h}$. After that 100 nM ADM (Phoenix Pharmaceuticals, Burlingame, CA) 
was added into the culture medium and incubated for another $6 \mathrm{~h}$. Pre-incubated follicles were also treated with 100 nM ET-1 (Phoenix Pharmaceuticals, Burlingame, CA). All the incubations were carried out at $37^{\circ} \mathrm{C}$ under $95 \%$ humidity and $5 \% \mathrm{CO}_{2}$. As to $\mathrm{CL}, \mathrm{CL}$ from 6-8 rats were pooled together and divided randomly into a 24-well plate at $3 \mathrm{CL}$ per well in $0.5 \mathrm{ml}$ medium. The incubation procedure was the same as that of follicles. At the end of the incubation, culture media was collected for the measurement of ADM or ET-1 by enzyme immunoassay (EIA). Follicles/CL were harvested for protein measurement for the normalization of peptide production or for the study of the gene expression levels of $A d m$ and Et1 and their respective receptor components.

To study the effects of progesterone and HCG, 10 $\mathrm{nmol} / \mathrm{L}$ progesterone or $0.75 \mathrm{IU} / \mathrm{ml} \mathrm{HCG}$ was added into the culture medium after $1 \mathrm{~h}$ pre-incubation. After $6 \mathrm{~h}$ incubation, the CL was harvested to determine the mRNA levels of $A d m$ and its receptor components by real-time RT-PCR.

\section{Short-time incubation of $\mathrm{CL}$ from pregnant rats}

Proestrus females were caged with proven fertile males overnight and the presence of vaginal sperm in the following morning was taken as evidence of successful copulation. This was day 1 of pregnancy. To study the effect of ADM on steroidogenesis, CL from ovaries of 7-day, 12-day and 17-day pregnant rats were isolated under a dissecting microscope with two $26 \mathrm{G} 1 / 2$ syringe needles in ice-cold normal saline. CL from 5-6 rats of each gestational age were dissected out, pooled and randomly divided into a 24-well plate at 3-4 CL per well in $0.5 \mathrm{ml}$ DMEM/F-12 medium. First, the isolated $\mathrm{CL}$ was pre-incubated in $37^{\circ} \mathrm{C}$ for $1 \mathrm{~h}$. The medium was replaced and a receptor antagonist, $1 \mu \mathrm{M}$ $\mathrm{hADM}_{22-52}$ or $1 \mu \mathrm{M} \mathrm{hCGRP}_{8-37}$, was added into the culture medium and incubated for $1 / 2 \mathrm{~h}$. After that $100 \mathrm{nM}$ ADM was added into the culture medium. At the end of $6 \mathrm{~h}$ incubation, the culture medium was collected for the measurement of progesterone production by EIA. The CL was harvested for protein measurement by a Pierce BCA protein assay kit (Thermo Scientific, Rockford, IL, USA) for the normalization of the hormone production.

\section{Short-time incubation of placenta}

The placentae of 12-day and 17-day pregnant rats were dissected out, and each was cut into 16 or 32 pieces in ice-cold normal saline. Three pieces of placenta tissue were randomly distributed in one well of a 24-well plate. The incubated procedure was the same as that for the short-time incubation of CL, except that the volume of the culture medium was $1.0 \mathrm{ml}$ instead of $0.5 \mathrm{ml}$. The culture media and placenta tissues were collected for progesterone EIA and protein normalization by Pierce BCA protein assay respectively.

\section{Genes expression of Adm, Crlr, Ramp1, Ramp2, Ramp3, Et1, Eta and Etb}

Total RNA of the follicles and corpus luteum were extracted using TRIZOL reagent and subjected to realtime RT-PCR analysis. RNA samples $(1 \mu \mathrm{g})$ were reverse transcribed into cDNA with the iScript reverse transcriptase according to the manufacturer's instructions (Bio-Rad Laboratories, Hercules, CA). The real-time RTPCR setup was previously described [12]. The reaction mixtures contained $25 \mu \mathrm{l}$ iQ SYBR Green Supermix (Bio-Rad Laboratories, Hercules, CA), $500 \mathrm{nM}$ of each primer, $1 \mu$ template $\mathrm{cDNA}$, and DNase-free water to a final volume of $50 \mu \mathrm{l}$. Cycle conditions were $95^{\circ} \mathrm{C}$ for 10 min, followed by 40 cycles of $95^{\circ} \mathrm{C}$ for $45 \mathrm{sec}, 59^{\circ} \mathrm{C}$ for $30 \mathrm{sec}$, and $72^{\circ} \mathrm{C}$ for $45 \mathrm{sec}$. The reaction was completed with a dissociation step for melting point analysis from $50^{\circ} \mathrm{C}$ to $95^{\circ} \mathrm{C}$ (in increments of $0.5^{\circ} \mathrm{C}$ for $10 \mathrm{sec}$ each. The primers were designed on the basis of the published sequences of $A d m$ (caggacaagcagagcacgtc, forward; tctggcggtagcgtttgac, reverse); Crlr (ccaaacagacttgggagtcactagg, forward; gctgtcttctctttctcatgcgtgc, reverse); Ramp1 (cactcactgcaccaaactcgtg, forward; cagtcatgagcagtgtgaccgtaa, reverse); Ramp2 (aggtattacagcaacctgcggt, forward; acatcctctgggggatcggaga, reverse); Ramp3 (acctgtcggagttcatcgtg, forward; acttcatccggggggtcttc, reverse); Et1(tctcttgcctcttcttgctgtc, forward; gaaactccgcctgctatgg, reverse); Eta (ccgtctatgatgagatggataag, forward; ggttgccaggttaatgcc, reverse) Etb (ccgtgcgagactgaaaac, forward; ccgagaagagatggtgtgg, reverse) and $A c t b$ (ggaaatcgtgcgtgacatta, forward; aggaaggaaggctggaagag, reverse). Standard curves for each gene product were prepared using serial dilution of the cDNA to determine PCR efficiency. The PCR efficiencies for Adm, Crlr, Ramp1, Ramp2, Ramp3, Et1, Eta and Etb and $A c t b$ were all above 0.95 and similar. The relative gene expression levels normalized to $A c t b$ were analyzed using the $\triangle \Delta C T$ method, where $C T$ was the cycle threshold. Melt curve analysis for each primer set revealed only one peak for each product. The size of the PCR products was confirmed by comparing the size of product with a commercial ladder after agarose gel electrophoresis.

\section{Extraction of peptides from culture medium}

The peptides in the culture medium were extracted, purified and concentrated by reversed-phase extraction using Sep-Pak ${ }^{\circledR}$ Vac C18 Cartridges (200 mg, Waters Corp., Milford, Massachusetts, USA). The peptides in the eluate were then concentrated by a Savant speedvacuum concentrator (Savant, Farmingdale, NY, USA) for $2 \mathrm{~h}$ and freeze-dried in a lypholizer (Labconco Corp, 
Kansas City, MO, USA) overnight. The dried extract was re-constituted in $1 \times$ EIA assay buffer. The peptide level in the culture medium was normalized by the amount of protein in the tissue as measured by the Pierce BCA protein assay kit.

\section{Extraction of peptides from follicles and $\mathrm{CL}$}

Follicles and corpora lutea were homogenized in $2 \mathrm{~N}$ ice-cold acetic acid and then boiled for $10 \mathrm{~min}$. A $50 \mu \mathrm{l}$ aliquot was taken for Bio-Rad protein assay (Bio-Rad Laboratories, Hercules, CA) for normalization. The remaining homogenates were centrifuged at 18, $600 \times \mathrm{g}$ for $20 \mathrm{~min}$ at $4^{\circ} \mathrm{C}$. The supernatants were lyophilized and stored at $-20^{\circ} \mathrm{C}$ until assayed for ADM immunoreactivity.

\section{Enzyme Immuno Assay (EIA)}

An ADM 1-50 (rat) EIA kit (Phoenix Pharmaceuticals, Inc, Burlingame, CA, USA) was employed to measure ADM. The minimum detectable concentration is 0.15 $\mathrm{ng} / \mathrm{ml}$ and the range is $0-100 \mathrm{ng} / \mathrm{ml}$. The intra-assay error and inter-assay error were less than 5\% and 14\% respectively. ET-1 was measured with an ET-1 EIA kit (Phoenix Pharmaceuticals, Inc, Burlingame, CA, USA). The minimum detectable concentration is $0.1 \mathrm{ng} / \mathrm{ml}$ and the range is $0-25 \mathrm{ng} / \mathrm{ml}$. The intra-assay error and inter-assay error were less than $5-10 \%$ and $15 \%$ respectively.

The progesterone EIA kit (MP Biomedicals, NY) has a minimum detectable concentration of $0.3 \mathrm{ng} / \mathrm{ml}$ and a range of 0-50 ng/ml. The intra-assay error and interassay error for this progesterone EIA kit is $2.4 \%$ and $2.6 \%$ respectively. The oestradiol EIA kit (MP Biomedicals, NY) has a minimum detectable concentration of 10 $\mathrm{pg} / \mathrm{ml}$ and a range of $0-1000 \mathrm{pg} / \mathrm{ml}$. The intra-assay error and inter-assay error for oestradiol EIA kit is $4.9 \%$ and $6.6 \%$ respectively.

\section{Statistical analysis}

All data were expressed as mean \pm SEM, and statistical significance was assessed by one-way ANOVA followed by Fisher's least significant difference test for post-hoc comparisons. Statistical significance was taken at the P $<0.05$ level.

\section{Results \\ ADM and gene expression of $A d m$ and its receptor components in follicles and $\mathrm{CL}$}

The gene expression level of $A d m$ and Ramp2 in large antral follicles and CL were much higher than those in small antral follicles (Figure 1A), while the expression levels of Crlr, Ramp1 and Ramp3 showed no significant difference (Figure 1A). There was no significant difference in the gene expression levels in either $A d m$ or its receptor components between LAF and CL. After $6 \mathrm{~h}$ incubation, large antral follicles secreted more, and CL secreted less, ADM into the medium than small antral follicles (Figure 1B). The tissue levels of ADM peptide were lower in large antral follicles and CL compared with small antral follicles (Figure 1B).

\section{Interaction of ADM and ET-1 in follicles}

After $6 \mathrm{~h}$ incubation, ET-1 reduced ADM secretion and the mRNA levels of $A d m$ and Ramp1, but not Crlr, Ramp 2 and Ramp3, in the large antral follicle (Figure 2A). On the contrary, ADM treatment up-regulated Et1 mRNA levels without affecting those of Eta and Etb receptors and ET-1 secretion (Figure 2B). The stimulatory effect of ADM on Et1 expression could not be abolished by either hADM $22-52$ (an ADM receptor antagonist) or hCGRP $_{8-37}$ (a CGRP receptor antagonist) (Figure 2B).

\section{Interaction of $\mathrm{ADM}$ and $\mathrm{ET}-1$ in $\mathrm{CL}$ and regulation of $\mathrm{ADM}$} expression by progesterone and HCG

ET-1 reduced $A d m$ gene expression and ADM secretion in the CL after $6 \mathrm{~h}$ incubation (Figure 3A) while ADM treatment increased Et1 expression level, an effect which was abolished by a CGRP receptor blocker - hCGRP $_{\text {8-37 }}$ (Figure 3B). Both progesterone and HCG suppressed $A d m$ expression but had no significant effect on the expression levels of Crlr, Ramp1, Ramp2 or Ramp3 (Figure 4).

\section{Effect of ADM on follicular growth and oestradiol secretion}

The cultured follicles were examined daily under microscopy. Most of the cultured preantral follicles increased in size and their diameter increased from $185.9 \pm 3.1$ $\mu \mathrm{m}$ to $347.6 \pm 18.0 \mu \mathrm{m}$ after $96 \mathrm{~h}$ incubation. There was no significant difference in follicular size between the control and ADM-treated group after $24 \mathrm{~h}, 48 \mathrm{~h}$ and 96 $\mathrm{h}$ incubation. However, oestradiol secretion into the culture medium of ADM-treated group $(960.8 \pm 136.1 \mathrm{pg} /$ follicle) was significantly higher than the control group $(600.5 \pm 98.8 \mathrm{pg} /$ follicle $)$.

\section{Effect of ADM on progesterone production from $\mathrm{CL}$ and placenta of pregnancy}

As shown in Figure 5A, the basal rates of progesterone production from CL of early, mid- and late pregnant rats were different, with the highest progesterone production rate at mid-pregnancy. Treatment with $1 \mathrm{nM}$ or $10 \mathrm{nM}$ ADM had no effect on progesterone production (data not shown). However, 100 nM ADM showed different effects on progesterone production in CL at different stages of gestation - inhibitory in early pregnancy (Figure 5B) and late pregnancy (Figure 5D) but 


\section{A}

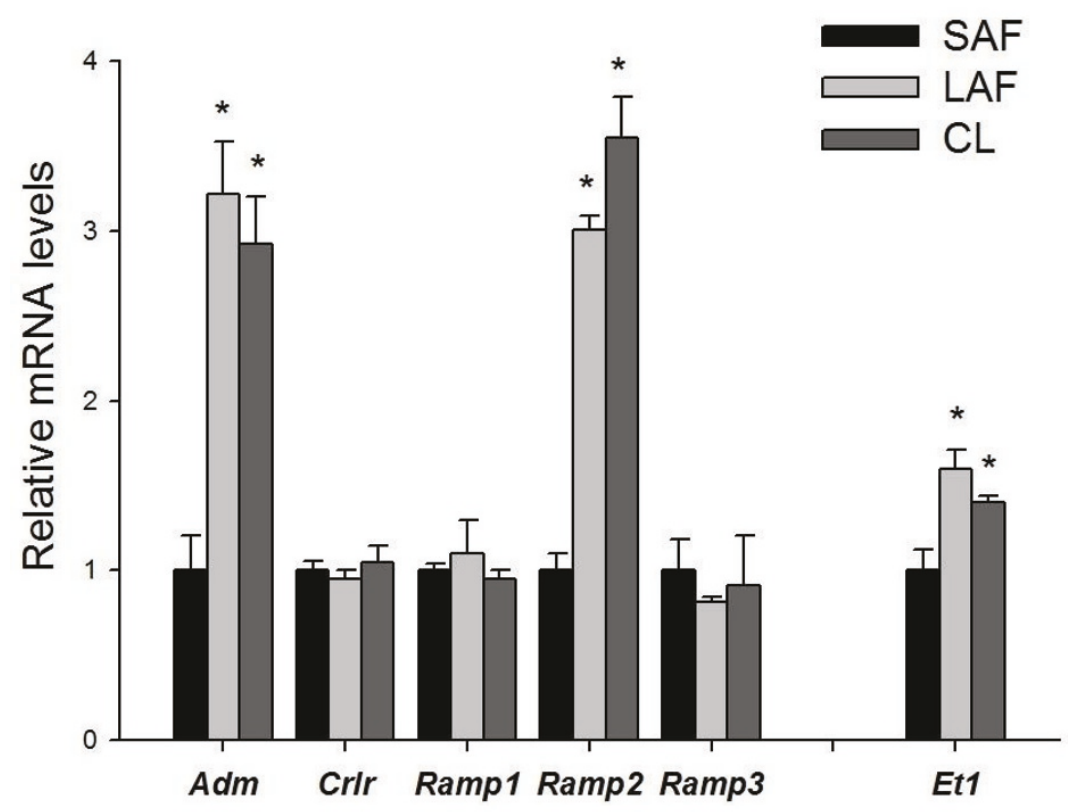

B

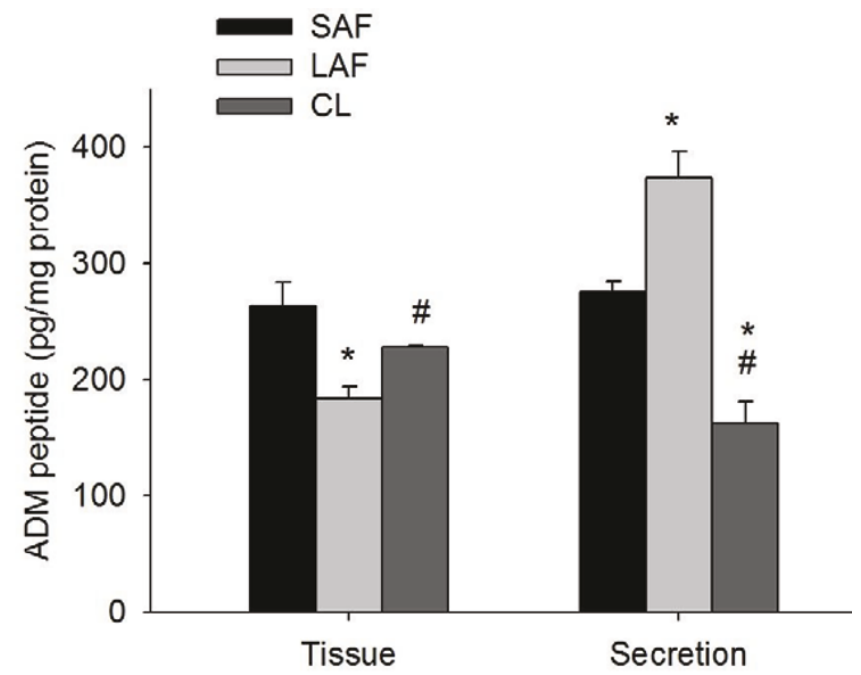

Figure 1 The peptide and gene expression levels of adrenomedullin in follicles and corpus luteum (CL). The gene expression levels of $A d m$, its receptor components and Et1 in small antral follicles (SAF), large antral follicles (LAF) and newly-formed corpus luteum (CL) (A); tissue levels of ADM and secreted ADM levels from SAF, LAF and $C L$ after $6 \mathrm{~h}$ incubation (B). $n=5$. ${ }^{*} P<0.05$ compared with SAF; \#P $<0.05$ compared with LAF. 

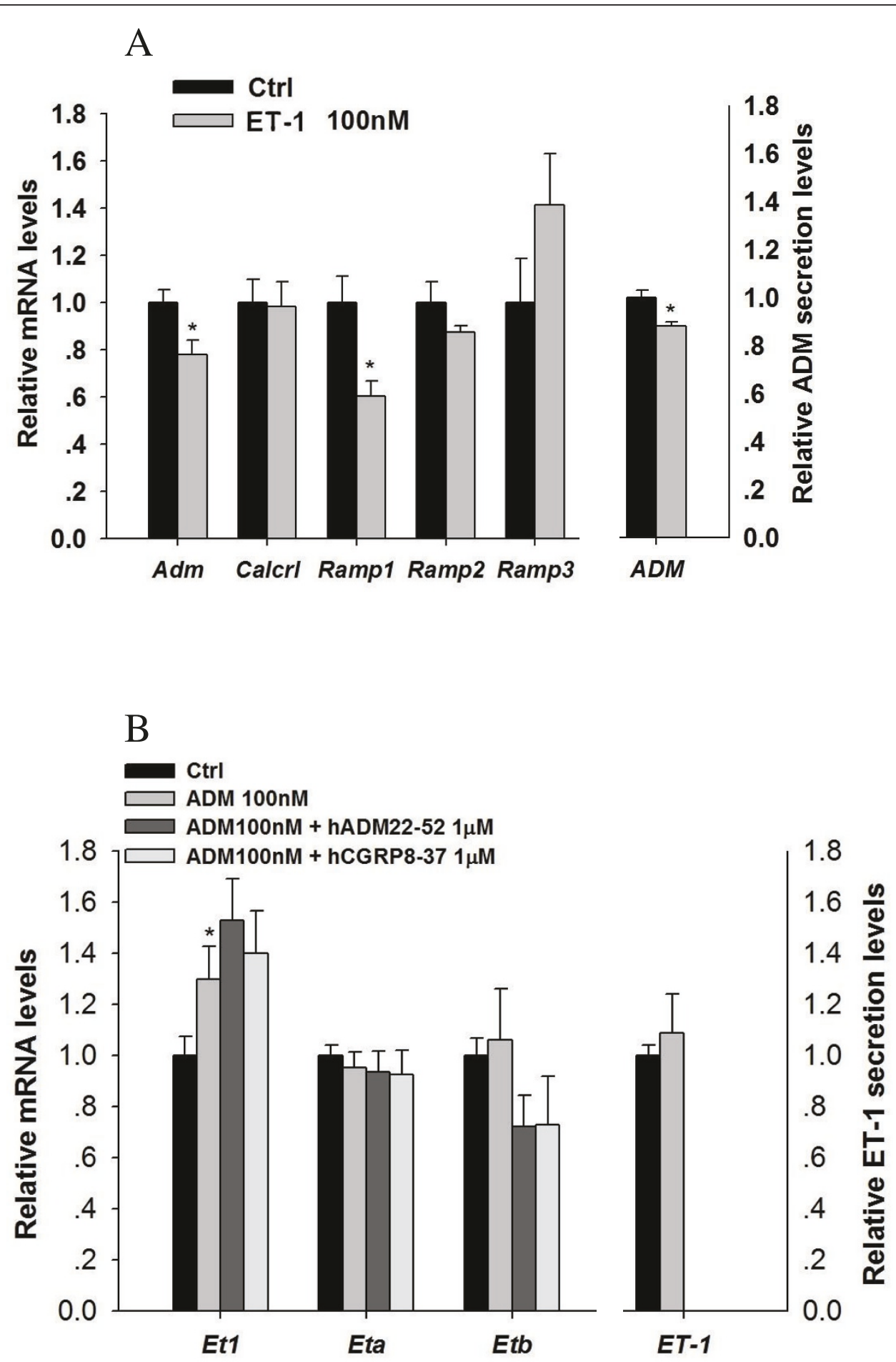

Figure 2 Interactions of ADM and ET-1 in large antral follicles. ET-1 reduced the gene expression levels of Adm and Ramp 1, and the ADM peptide secretion level (A); ADM treatment up-regulated Et1 gene expression level (B). Data were presented as mean \pm SEM. $n=5$; *P $<0.05$ compared with control. 

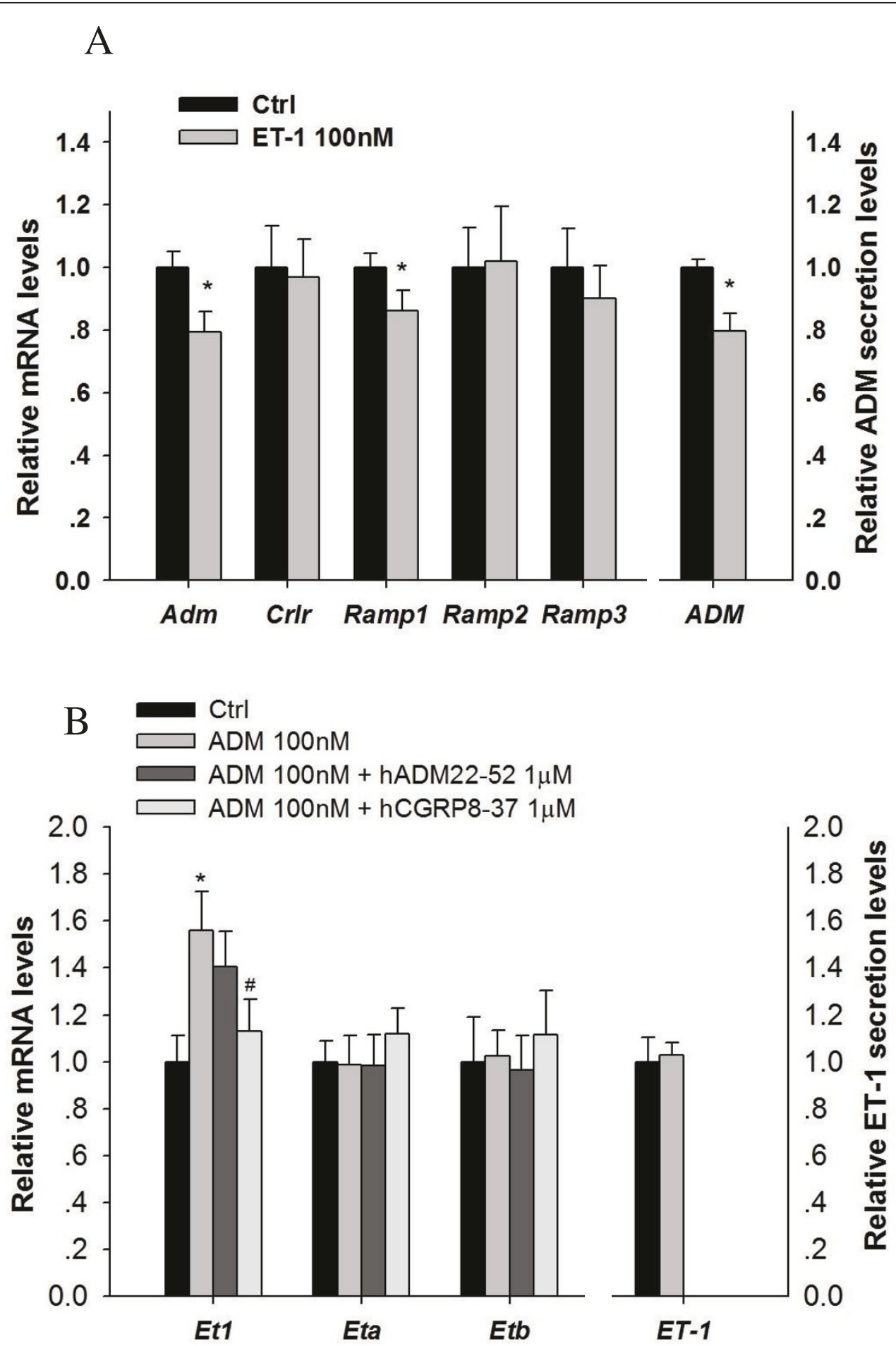

Figure 3 Interactions of $\mathbf{A D M}$ and ET-1 in corpus luteum (CL). ET-1 reduced Adm and Ramp1 gene expression and ADM secretion in the CL (A); ADM treatment increased Et1 expression level, which was reversed by a CGRP receptor blocker - $h C_{\text {CGRP-37 }}$ (B). $n=6-8$; *P $<0.05$ compared with control, \#P $<0.05$ compared with 100 nM ADM treatment group. 


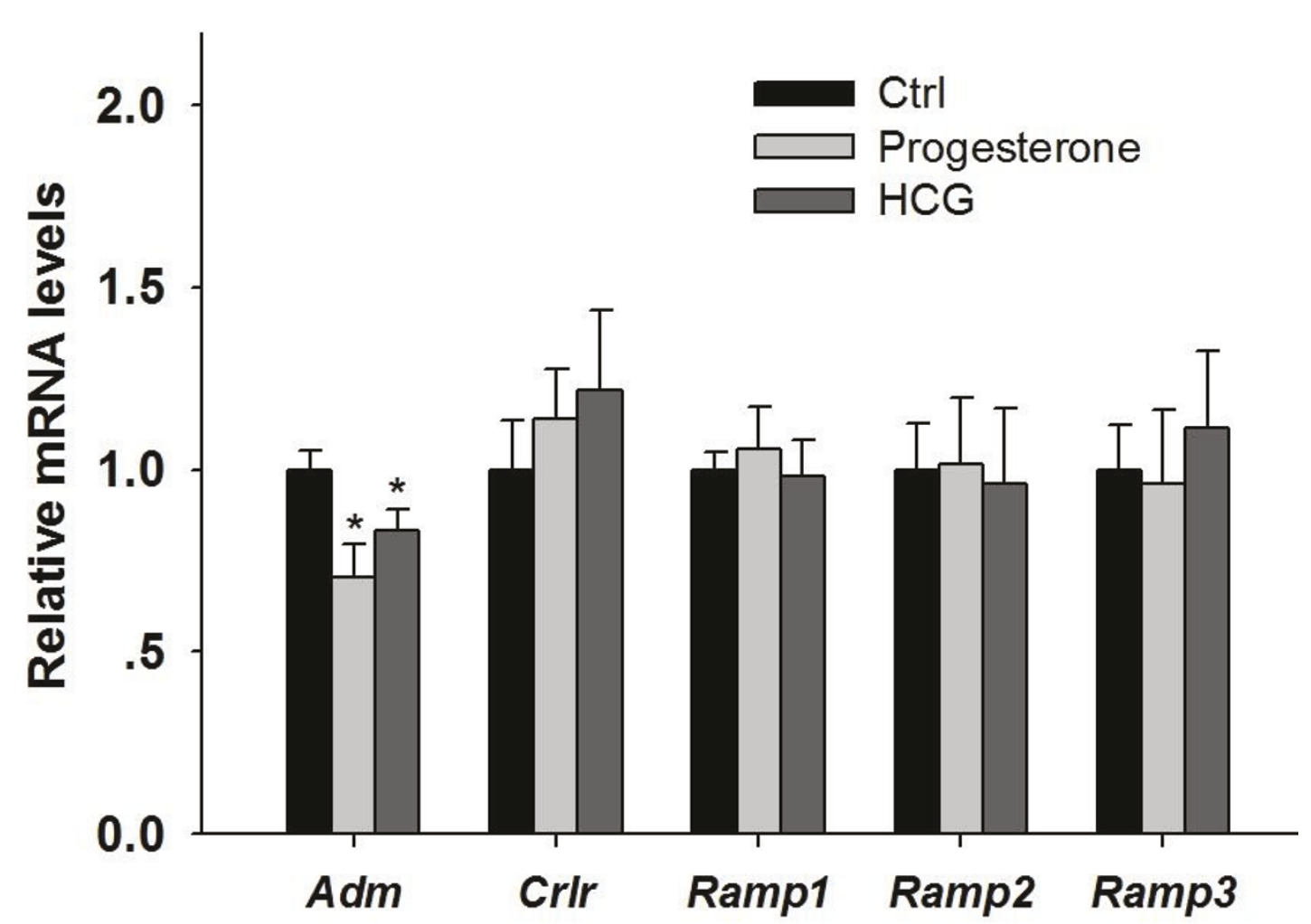

Figure 4 Regulation of gene expression of $A d m$ and its receptor components in the corpus luteum (CL) by progesterone and HCG. Progesterone and HCG both suppressed Adm expression. $n=5$; ${ }^{*} \mathrm{P}<0.05$ compared with control.

stimulatory in mid-pregnancy (Figure 5C). The inhibitory effect in early pregnancy and the stimulatory effect at mid-pregnancy were reversed by the CGRP receptor antagonist, hCGRP $_{8-37}$.

The secretion level of progesterone from the placenta was extremely low compared with those in CL, with $11.4 \pm 4.7$ and $3.6 \pm 0.2 \mathrm{nmol} / \mathrm{g}$ protein $/ 6 \mathrm{~h}$ for placenta of mid- and late pregnancy respectively. A CL produced much more progesterone than a placenta $(184.4 \pm 50.2$ and $208.9 \pm 32.3$ picomol per CL vs $19.4 \pm 17.5$ and $19.4 \pm 2.7$ picomol per placenta at mid- and late pregnancy). ADM had no effect on progesterone production in placentae (data not shown).

\section{Discussion}

In the rat, the recruitment of follicles into the ovulatory cohort occurs around the time of antrum formation with a follicle diameter of about 200-400 $\mu \mathrm{m}$, concomitant with the atresia of most of the follicles [34]. Ovulation occurs when the follicles reach a size of 900-1000 $\mu \mathrm{m}$ in diameter [34]. The finding of a higher ADM secretion and $A d m$ mRNA level in large antral follicles and CL compared with small antral follicles agrees well with the previous qualitative description of increased
ADM and $A d m$ mRNA expression in the human CL [9], and suggests a possible role of ADM in follicle development, luteogenesis and/or steroidogenesis. High Ramp2 gene expression levels in large antral follicles and CL compared to small antral follicles suggests a possible further augmentation of ADM function through the increase in an ADM receptor.

After a short 6-h incubation, large antral follicles secreted the largest amount of ADM peptide into the medium. High ADM level in human follicular fluid has been reported and the pre-ovulatory level is even higher than the plasma ADM concentration $[10,24,25]$. The possible function of secreted ADM from the large antral follicles remained unknown. After ovulation the ADM in the residual follicular fluid that enters the oviduct together with the oocyte may exert biological actions in the fallopian tube and the uterus, such as the regulation of blood flow [35], sperm transportation [36,37] and uterine contraction [10].

$\mathrm{ADM}$ at the dose of $100 \mathrm{nM}$ had no effects on the follicular size and follicular survival rate. In the heterozygous $A d m$ knockout mouse with decreased $A d m$ expression and reduced fertility, there was also no significant decrease in ovulation, fertilization rate or overt 


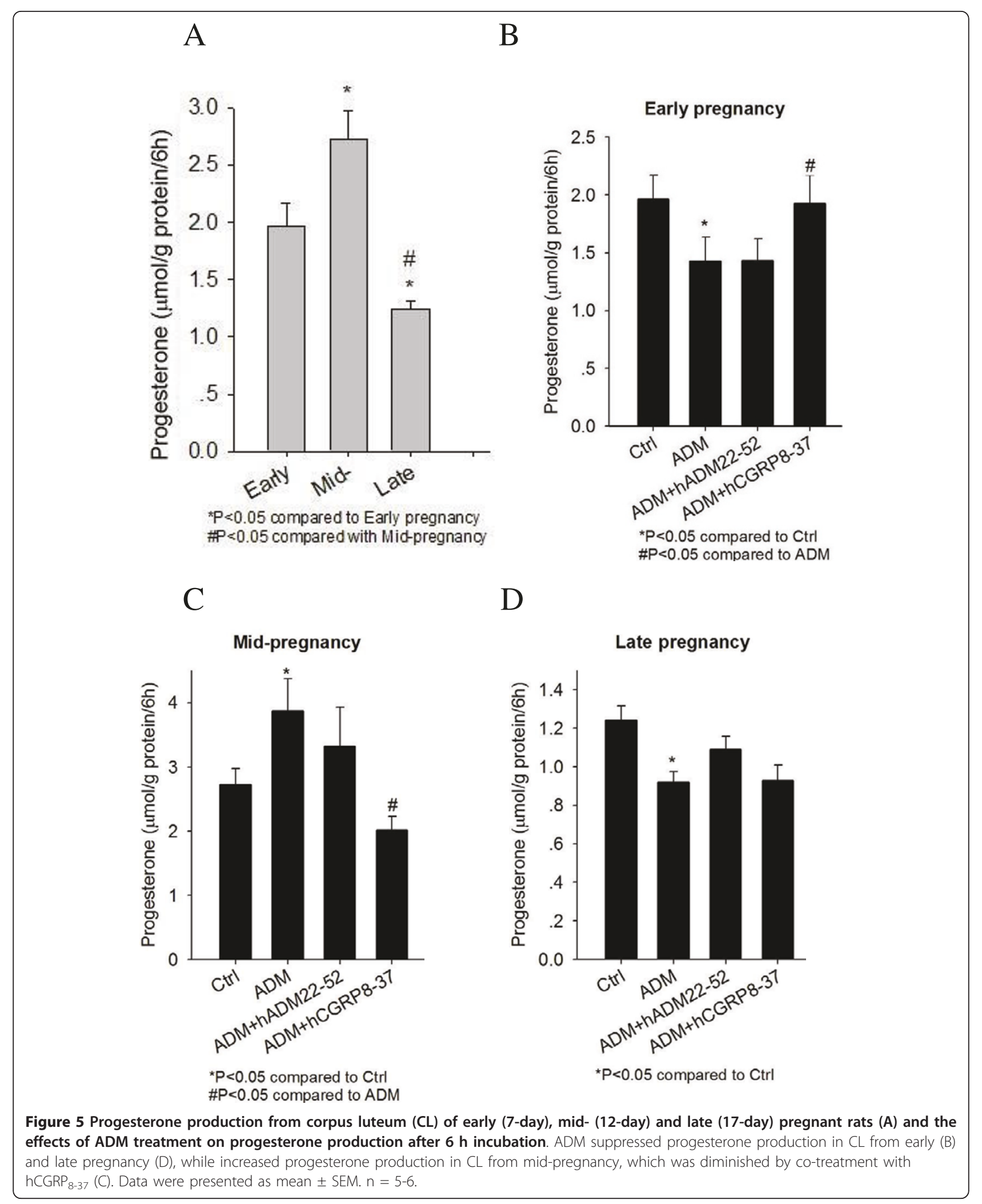


defects in folliculogenesis or CL formation [38]. On the other hand, ADM was found to stimulate oestradiol production from the follicles, suggesting a role for ADM in steroidogenesis rather than granulosa cell proliferation.

The relative high levels of ADM and the gene expression level of $A d m$ and Ramp2 in the newly-formed CL also suggested that ADM might be involved in CL formation or luteal functions. Indeed our group has reported an inhibitory effect of ADM on eCG-stimulated progesterone secretion from CL [12]. The CL employed in that report were isolated from eCG primed rats, which were not fully functional as compared to the CL of pregnant rats. We therefore used CL from early, mid- and late pregnant rats for this study. It is of interest to note that ADM showed opposite effects on progesterone production depending on the pregnancy stage, inhibitory in CL from early and late pregnant rat while stimulatory in CL from mid-pregnant rats. This dual role of ADM in progesterone production may partly explain for the differences in the basal progesterone production from the CL at different pregnancy stages. CL of mid-pregnancy produced the greatest amount of ADM when the effect of ADM is stimulatory, not forgetting that the low basal progesterone secretion from the CL of late pregnancy could be due to the decrease in $\mathrm{LH}$ and prolactin secretion from early pregnancy onwards [39] while the increase in progesterone production in mid-pregnancy could be due to the secretion of placental luteotopin with prolactin activity from day 6 to day 11 of pregnancy [40]. Prolactin [41] and placental luteotropins [42] are known to stimulate luteal progesterone production

The difference in ADM effects on progesterone production cannot be simply due to the binding to different receptors as both the inhibitory effect in early pregnancy and the stimulatory effect in mid-pregnancy were blocked by the CGRP receptor antagonist. In late pregnancy, the inhibitory effect was more likely mediated by the ADM receptor. A similar dual effect has been reported for the actions of progesterone on prolactin secretion, with a stimulatory effect in early pregnancy (day 7) and an inhibitory effect in late pregnancy (day 17) [43]. The suppressive action of progesterone on $A d m$ gene expression may suggest the presence of a negative feedback between ADM and progesterone. The inhibitory effect of hCG on CL $A d m$ gene expression is in line with the FSH effect in the follicles [8].

Compared with $\mathrm{CL}$, the progesterone production from placenta was minor. This is consistent with existing literature that the progesterone production in rat CL was not taken over by placenta from mid-pregnancy onwards, unlike the situation in human pregnancy [44]. In our study, progesterone production of the placenta decreased from mid-pregnancy to late pregnancy, in line with the finding of Matt and MacDonald [44].

It was found that in both the follicle and CL, ADM and ET-1 showed opposite regulatory effect on each other, indicating the presence of an autocrine/paracrine regulatory loop between ADM and ET-1. ADM stimulated the gene expression level of Et1 in the CL, an effect which is abolished by CGRP receptor blocker hCGRP $_{8-37}$. As ET-1 was reported to inhibit progesterone production in the rat CL [26], the stimulatory effect of ADM on Et1 gene expression might in turn suppress progesterone production. On the other hand, ET-1 treatment suppressed both the ADM peptide secretion and its gene expression in CL. This finding is opposite to the results in both the Leydig and Sertoli cells, in which ADM decreases ET-1 level but ET-1 increases ADM level $[15,16]$. It suggests that besides a direct inhibitory effect, ET-1 may also fine-tune progesterone production through its suppressive effects on ADM secretion and $A d m$ gene expression. In addition to the functional interaction of ADM and ET-1 in regulating progesterone, in the $\mathrm{CL}, \mathrm{ADM}$ may also have actions opposite to those of ET-1 in luteolysis. ET-1 is suggested to be luteolytic $[26,45]$ while ADM may be antiluteolytic [9] by maintaining adequate luteal blood flow as a vasodilator.

\section{Conclusions}

In conclusion, the gene expression of $A d m$ and ADM secretion increased with the change from small antral follicles to large antral follicles and CL. ADM in the follicle was involved in steroidogenesis. In CL of pregnancy, the regulation of ADM on progesterone production was pregnancy stage - dependent, inhibitory in CL from early and late pregnancy while stimulatory at mid-pregnancy. Moreover, there was the interaction between ADM and ET-1 at both the production and functional levels in CL. Besides prolactin and placental luteotropins, ADM may be an important regulator in progesterone production during pregnancy, being itself under the inhibitory effects of $\mathrm{LH}$, progesterone and ET-1.

\section{Acknowledgements}

This study was substantially supported by a grant from the Research Grants Council (RGC) of the Hong Kong Special Administrative Region, China (HKU 7736/07M) and a grant from the Elaine GCF Tso Memorial Fund Committee of Management, the University of Hong Kong.

\section{Author details}

'Department of Physiology, Li Ka Shing Faculty of Medicine, The University of Hong Kong, Pokfulam, Hong Kong SAR, China. 'Department of Anatomy, Li Ka Shing Faculty of Medicine, The University of Hong Kong, Pokfulam, Hong Kong SAR, China. ${ }^{3}$ Centre of Reproduction, Development and Growth, Li Ka Shing Faculty of Medicine, The University of Hong Kong, Pokfulam, Hong Kong SAR, China. ${ }^{4}$ Centre of Heart, Brain, Hormone and Healthy Aging, 
Li Ka Shing Faculty of Medicine, The University of Hong Kong, Pokfulam, Hong Kong SAR, China.

\section{Authors' contributions}

$\mathrm{LL}$ worked on mating of rats, collection of tissues, in vitro culture of the tissues, real time PCR, ELISA and drafted the manuscript. WSO and FT coordinated the project. WSO and FT are respectively principal and coinvestigators of the research and holders of the grant. Both WSO and FT helped in the revision of the manuscript. All authors read and approved the final manuscript.

\section{Competing interests}

The authors declare that they have no competing interests.

Received: 19 June 2011 Accepted: 9 August 2011

Published: 9 August 2011

\section{References}

1. Kitamura K, Kangawa K, Kawamoto M, Ichiki Y, Nakamura S, Matsuo H, Eto T: Adrenomedullin: a novel hypotensive peptide isolated from human pheochromocytoma. Biochem Biophys Res Commun 1993, 192:553-560.

2. Sakata J, Shimokubo T, Kitamura K, Nakamura S, Kangawa K, Matsuo H, Eto T: Molecular cloning and biological activities of rat adrenomedullin, a hypotensive peptide. Biochem Biophys Res Commun 1993, 195:921-927.

3. Kitamura K, Sakata J, Kangawa K, Kojima M, Matsuo H, Eto T: Cloning and characterization of cDNA encoding a precursor for human adrenomedullin. Biochem Biophys Res Commun 1993, 194:720-725.

4. Kitamura K, Kangawa K, Kojima M, Ichiki Y, Matsuo H, Eto T: Complete amino acid sequence of porcine adrenomedullin and cloning of CDNA encoding its precursor. FEBS Lett 1994, 338:306-310.

5. Kitamura K, Matsui E, Kato J, Katoh F, Kita T, Tsuji T, Kangawa K, Eto T: Adrenomedullin (11-26): a novel endogenous hypertensive peptide isolated from bovine adrenal medulla. Peptides 2001, 22:1713-1718.

6. Hwang IS, Tang F: Peripheral distribution and gene expression of adrenomedullin in the rat: possible source of blood adrenomedullin. Neuropeptides 2000, 34:32-37.

7. Cameron VA, Fleming AM: Novel sites of adrenomedullin gene expression in mouse and rat tissues. Endocrinology 1998, 139:2253-2264.

8. Abe K, Minegishi T, Tano M, Hirakawa T, Tsuchiya M, Kangawa K, Kojima M, Ibuki Y: Expression and effect of adrenomedullin on rat granulosa cell. Endocrinology 1998, 139:5263-5266.

9. Abe K, Minegishi T, Ibuki Y, Kojima M, Kangawa K: Expression of adrenomedullin in the human corpus luteum. Fertil Steril 2000, 74:141-145.

10. Moriyama T, Otani T, Maruo T: Expression of adrenomedullin by human granulosa lutein cells and its effect on progesterone production. Eur J Endocrinol 2000, 142:671-676.

11. Upton PD, Austin C, Taylor GM, Nandha KA, Clark AJ, Ghatei MA, Bloom SR, Smith DM: Expression of adrenomedullin (ADM) and its binding sites in the rat uterus: increased number of binding sites and ADM messenger ribonucleic acid in 20-day pregnant rats compared with nonpregnant rats. Endocrinology 1997, 138:2508-2514

12. Li YY, Li L, Hwang IS, Tang F, WS O: Coexpression of adrenomedullin and its receptors in the reproductive system of the rat: effects on steroid secretion in rat ovary. Biol Reprod 2008, 79:200-208.

13. Sakata J, Shimokubo T, Kitamura K, Nishizono M, lehiki Y, Kangawa K, Matsuo $H$, Eto T: Distribution and characterization of immunoreactive rat adrenomedullin in tissue and plasma. FEBS Lett 1994, 352:105-108.

14. Li YY, Hwang IS, WS O, Tang F: Adrenomedullin peptide: gene expression of adrenomedullin, its receptors and receptor activity modifying proteins, and receptor binding in rat testis-actions on testosterone secretion. Biol Reprod 2006, 75:183-188.

15. Chan YF, WS O, Tang F: Adrenomedullin in the rat testis. I: Its production, actions on testosterone secretion, regulation by human chorionic gonadotropin, and its interaction with endothelin 1 in the leydig cell. Biol Reprod 2008, 78:773-779.

16. Chan YF, Tang F, WS O: Adrenomedullin in the rat testis. II: Its production, actions on inhibin secretion, regulation by folliclestimulating hormone, and its interaction with endothelin 1 in the Sertoli cell. Biol Reprod 2008, 78:780-785.
17. Pewitt EB, Haleem R, Wang Z: Adrenomedullin gene is abundantly expressed and directly regulated by androgen in the rat ventral prostate. Endocrinology 1999, 140:2382-2386.

18. Jimenez N, Calvo A, Martinez A, Rosell D, Cuttitta F, Montuenga LM: Expression of adrenomedullin and proadrenomedullin N-terminal 20 peptide in human and rat prostate. J Histochem Cytochem 1999, 47:1167-1178

19. Hwang IS, Autelitano DJ, Wong PY, Leung GP, Tang F: Co-expression of adrenomedullin and adrenomedullin receptors in rat epididymis: distinct physiological actions on anion transport. Biol Reprod 2003, 68:2005-2012.

20. Eguchi S, Hirata Y, Kano H, Sato K, Watanabe Y, Watanabe TX, Nakajima K, Sakakibara S, Marumo F: Specific receptors for adrenomedullin in cultured rat vascular smooth muscle cells. FEBS Lett 1994, 340:226-230.

21. Entzeroth M, Doods HN, Wieland HA, Wienen W: Adrenomedullin mediates vasodilation via CGRP1 receptors. Life Sci 1995, 56:PL19-25.

22. Kapas S, Catt KJ, Clark AJ: Cloning and expression of CDNA encoding a rat adrenomedullin receptor. J Biol Chem 1995, 270:25344-25347.

23. McLatchie LM, Fraser NJ, Main MJ, Wise A, Brown J, Thompson N, Solari R, Lee MG, Foord SM: RAMPs regulate the transport and ligand specificity of the calcitonin-receptor-like receptor. Nature 1998, 393:333-339.

24. Manau D, Balasch J, Jimenez W, Fabregues F, Civico S, Casamitjana R, Creus M, Vanrell JA: Follicular fluid concentrations of adrenomedullin, vascular endothelial growth factor and nitric oxide in IVF cycles: relationship to ovarian response. Hum Reprod 2000, 15:1295-1299.

25. Manau D, Balasch J, Jimenez W, Fabregues F, Casamitjana R, Creus M, Arroyo V, Vanrell JA: Adrenomedullin and nitric oxide in menstrual and in vitro fertilization cycles. Relationship to estradiol. Acta Obstet Gynecol Scand 1999, 78:626-631.

26. Girsh E, Dekel N: Involvement of endothelin-1 and its receptors in PGF2 alpha-induced luteolysis in the rat. Mol Reprod Dev 2002, 63:71-78.

27. Shubeita HE, MCDonough PM, Harris AN, Knowlton KU, Glembotski CC, Brown JH, Chien KR: Endothelin induction of inositol phospholipid hydrolysis, sarcomere assembly, and cardiac gene expression in ventricular myocytes. A paracrine mechanism for myocardial cell hypertrophy. J Biol Chem 1990, 265:20555-20562.

28. Kohno M, Kano H, Horio T, Yokokawa K, Yasunari K, Takeda T: Inhibition of endothelin production by adrenomedullin in vascular smooth muscle cells. Hypertension 1995, 25:1185-1190.

29. Sugo S, Minamino N, Shoji H, Kangawa K, Matsuo H: Effects of vasoactive substances and cAMP related compounds on adrenomedullin production in cultured vascular smooth muscle cells. FEBS Lett 1995, 369:311-314.

30. Kohno M, Yasunari K, Yokokawa K, Horio T, Ikeda M, Kano H, Minami M Hanehira T, Yoskikawa J: Interaction of adrenomedullin and plateletderived growth factor on rat mesangial cell production of endothelin. Hypertension 1996, 27:663-667.

31. Araki S, Haneda M, Togawa M, Kikkawa R: Endothelin-1 activates c-Jun NH2-terminal kinase in mesangial cells. Kidney Int 1997, 51:631-639.

32. Parameswaran N, Nambi P, Hall CS, Brooks DP, Spielman WS: Adrenomedullin decreases extracellular signal-regulated kinase activity through an increase in protein phosphatase-2A activity in mesangial cells. Eur J Pharmacol 2000, 388:133-138.

33. Kapas S, Hinson JP: Actions of adrenomedullin on the rat adrenal cortex. Endocr Res 1996, 22:861-865.

34. Hirshfield AN: Development of follicles in the mammalian ovary. Int Rev Cytol 1991, 124:43-101

35. Yotsumoto S, Shimada T, Cui CY, Nakashima H, Fujiwara H, Ko MS Expression of adrenomedullin, a hypotensive peptide, in the trophoblast giant cells at the embryo implantation site in mouse. Dev Biol 1998, 203:264-275.

36. Fazeli A, Affara NA, Hubank M, Holt WV: Sperm-induced modification of the oviductal gene expression profile after natural insemination in mice. Biol Reprod 2004, 71:60-65.

37. Chiu PC, Liao S, Lam KK, Tang F, Ho JC, Ho PC, WS O, Yao YQ, Yeung WS: Adrenomedullin regulates sperm motility and oviductal ciliary beat via cyclic adenosine $5^{\prime}$-monophosphate/protein kinase $A$ and nitric oxide. Endocrinology 2010, 151:3336-3347.

38. Li M, Wu Y, Caron KM: Haploinsufficiency for adrenomedullin reduces pinopodes and diminishes uterine receptivity in mice. Biol Reprod 2008, 79:1169-1175. 
39. Yohkaichiya $\mathrm{T}, \mathrm{O}^{\prime}$ Connor $\mathrm{A}$, deKrestser DM: Circulating immunoreactive inhibin, gonadotropin, and prolactin levels during pregnancy, lactation, and postweaning estous cycle in the rat. Biol Reprod 1991, 44:6-12.

40. Jayatilak PG, Glaser LA, Warshaw ML, Herz Z, Gruber JR, Giboria G: Relationship betweeen luteinizing hormone and decdual luteotropin in the maintenace of luteal steroidogenesis. Biol Reprod 1984, 31:556-64.

41. Goyeneche AA, Martinez IL, Deis RP, Gibori G, Telleria CM: In vivo hormonal environment leads to differential susceptibility of the corpus luteum to apoptosis in vitro. Biol Reprod 2003, 68:2322-30.

42. Takiguchi S, Sugino N, Kashida S, Yamagata Y, Nakamura Y, Kato H: Rescue of the corpus luteum and an increase in luteal superoxide dismutase expression induced by placental luteotropins in the rat: action of testosterone without conversion to estrogen. Biol Reprod 2000, 62:398-403.

43. Jahn GA, Alonso N, Deis RP: Ovarian and feto-placental factors and the regulation of prolactin release during pregnancy in the rat. J Reprod Fertil 1986, 77:125-33.

44. Matt DW, MacDonald GJ: In vitro progesterone and testosterone production by the rat placenta during pregnancy. Endocrinology 1984 115:741-747.

45. Hinckley ST, Milvae RA: Endothelin-1 mediates prostaglandin F(2 alpha)induced luteal regression in the ewe. Biol Reprod 2001, 64:1619-1623.

doi:10.1186/1477-7827-9-111

Cite this article as: Li et al:: Adrenomedullin in rat follicles and corpora lutea: expression, functions and interaction with endothelin-1.

Reproductive Biology and Endocrinology 2011 9:111.

\section{Submit your next manuscript to BioMed Central and take full advantage of:}

- Convenient online submission

- Thorough peer review

- No space constraints or color figure charges

- Immediate publication on acceptance

- Inclusion in PubMed, CAS, Scopus and Google Scholar

- Research which is freely available for redistribution

Submit your manuscript at www.biomedcentral.com/submit 